\title{
Assessment of Critical Resource Use in Aircraft Manufacturing
}

\author{
lulia Dolganova ${ }^{1}$ (D) $\cdot$ Vanessa Bach $^{1}$ (D) Anne RödI ${ }^{2}$ (D) $\cdot$ Martin Kaltschmitt ${ }^{2}$ (D) \\ Matthias Finkbeiner ${ }^{1}$ (iD)
}

Received: 8 September 2021 / Accepted: 13 January 2022 / Published online: 1 March 2022

(c) The Author(s) 2022

\begin{abstract}
The global aircraft fleet has been expanding worldwide, leading to a high demand for primary resources. Simultaneously, recycling initiatives for decommissioned aircraft are still incipient. Following circular economy principles, the aims of this paper are to identify potentially critical resources used and related environmental impacts, to derive recommendations regarding recycling, and to analyze the influence of increasing utilization of lightweight composite materials in aircraft manufacturing. It was identified that the engine is the structure containing resources with the highest scarcity, with tantalum dominating seven of the eleven analyzed impact categories. Aluminum, titanium, and nickel were shown to lead to the highest environmental impacts. Hotspots in the criticality and environmental assessment often occur due to alloying resources with a low mass share. It was shown that aluminum and steel alloy recycling should be prioritized. A higher lightweight composite material share in the aircraft increases impacts in the categories climate change and fossil resource depletion by $12 \%$ and $20 \%$, respectively, whereas the impact of the category acidification, political stability, and demand growth decreases by $16 \%, 35 \%$, and $60 \%$, respectively.
\end{abstract}

Keywords Aircraft $\cdot$ Resources $\cdot$ ESSENZ $\cdot$ Criticality $\cdot$ Life cycle assessment

\section{Introduction}

The relevance of the air transportation sector has been increasing in the last decade, mainly driven by factors such as low air fares and better living standards [1]. According to the most recent forecasts, between 2017 and 2036, the number of airline passengers worldwide is expected to grow by an average of $4.7 \%$ yearly [2]. By 2037, the annual number of passengers is predicted to reach up to 8.2 billion [3]. To satisfy this increasing demand, the aircraft fleet will almost double in the next 20 years $[4,5]$.

Vanessa Bach

vanessa.bach@tu-berlin.de

1 Technische Universität Berlin, Strasse des 17. Juni 135, 10623 Berlin, Germany

2 Technische Universität Hamburg, Eissendorfer Strasse 40, 21073 Hamburg, Germany 
In the last 30 years, the primary resource demand rose worldwide by overall $50 \%$ $[6,7]$ and is projected to more than double from $79 \mathrm{Gt} / \mathrm{a}$ in 2011 to $167 \mathrm{Gt}$ in 2060 , whereas metals are expected to grow the fastest [8]. The global aerospace industry alone consumes 770 kilo tons of resource per year [9]. Simultaneously, the topic of resources' criticality has become more relevant in recent years due to limited availability of certain resources. Criticality is defined as supply risk (probability of supply disruption) and the vulnerability to this supply risk [10-12]. Several studies on country level (e.g., [13-16]) as well as product level (e.g., [12, 17-20]) including the mobility sector (e.g., [21-25]) have been carried out in recent years to assess resources' criticality.

In this context, a circular economy approach is a precondition for achieving climate neutral production processes. The concept of circular economy emerged in the last decade considering the scarcity of natural resources counterposed to the growing demand for them due to, e.g., increasing population. While most of the studies apply this concept for increasing the recycling or the reuse rate of products, a social dimension seems to be missing [26]. The ESSENZ method, applied in this paper, addresses the criticality of resources also incorporating societal aspects [27].

Usually, an aircraft is in operation for about 30 to 40 years. Considering the age of the current aircraft fleet, about 18,000 passenger aircraft will be decommissioned in the next 20 years [28]. Some aircrafts are used for spare parts, sold to developing countries or eventually brought back to service in the case of an increased demand. Notably, the most common practice for decommissioned aircraft is their disposal in deserts of former airports - the so-called aircraft graveyards [29, 30], where they are simply parked for an undefined time period. Even though some initiatives for aircraft recycling have been already developed and partly implemented (e.g., PAMELA project) [31-33]), they are still very incipient, also because there is no international regulation for the end-of-life handling of aircraft.

As aircraft are composed of a number of different resources, including aluminum, titanium, nickel, and steel alloys, which are easily recyclable [34], these aircraft graveyards can be seen as a great source for secondary resources, especially considering that some of these resources might become scarce in the next decades. Also, it was already demonstrated that $80-85 \%$ of an aircraft's weight could be recycled [32]. Thus, it should be identified which resources to focus on for recycling to reduce overall criticality and environmental impacts of the aircraft manufacturing.

As shown in Fig. 1, a new trend in the aircraft industry is the increased utilization of lightweight composite materials, such as carbon fiber reinforced plastic (CFRP) or glass fiber reinforced plastic (GFRP) [35, 36]. It is reported that the fuel use of aircraft with a higher proportion of composites materials is around $25 \%$ lower than a reference aircraft based mainly on aluminum parts [37]. Thus, the integration of composites materials in the aircraft manufacturing may significantly reduce emissions throughout the operation phase [38-40].

However, the resource use of aircraft during the production and recycling phases is not fully addressed in these publications. As carbon fibers are mainly produced from fossil fuels, their dependency on these resources is high. Methods for CFRP recycling are still under development [39, 42, 43]. Currently, lightweight composite resources are more likely to be landfilled or burnt than properly recycled [44-46]. Thus, a comprehensive assessment of environmental impacts and criticality of composite materials considering current and future use is also included in this paper. Overall, the aims of this paper are (i) to identify the most critical resources used in aircraft manufacturing applying the ESSENZ method [47, 48] — further explained in background "ESSENZ Method" section-(ii) to determine the environmental 


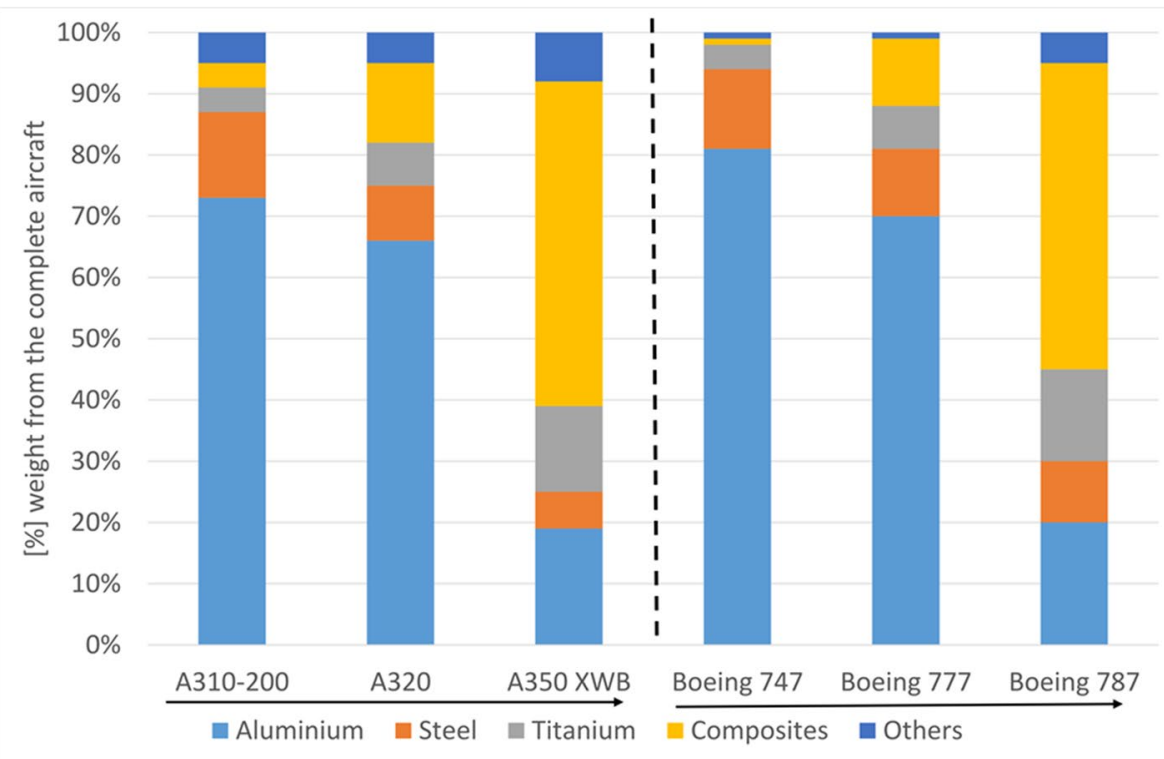

Fig. 1 Material trends for Airbus and Boeing aircraft based on a comparison designed by Ilg (2015) [41], showing the increasing share of composites materials in the most modern aircraft

impacts of the manufacturing phase; (iii) to derive recommendations regarding recycling of resources, and (iv) to analyze the influence of the increasing use of lightweight composite materials and their impacts on resource criticality and the environment.

The Airbus A330-200 was selected as a reference aircraft, exemplary for the entire aircraft which is a commercial passenger aircraft designed for medium to long-haul flights. Currently, there are approximately 416 active A330-200 airplanes, and 199 are being stored [49]. The use phase is not considered in this paper, although it has the largest environmental impact when considering the entire life cycle of aircraft [44], and the use of fossil-based jet fuels is a hotspot in terms of resource use in general as well as critical resources. However, as the use phase has these high impacts, the impacts of the manufacturing stage are comparably low. Thus, the manufacturing phase is being disregarded by most of the authors. The focus of this paper is deliberately on the manufacturing phase to identify hotspots only in this life cycle stage.

To achieve the aims of the paper, first the analyzed product system and the methodology ("Method") including the life cycle inventory are described. The results are presented for the criticality assessment including long-term availability ("Criticality Assessment Including Long-Term Availability"), environmental assessment ("Environmental Assessment"), recommendations regarding recycling of resources ("Recommendations Regarding Recycling of Resources"), and scenario analysis for increased use of lightweight composite information ("Scenario Analysis for Increased Use of Lightweight Composite Materials"). The underlying assumptions of the case study are discussed ("Discussion"), and conclusions are drawn ("Conclusions"). 


\section{Environmental and Social Impact Evaluation of Aircraft Production in Existing Literature}

There are only few publications depicting the LCA of an aircraft in detail. This is mainly due to the lack of public available data from aircraft manufacturers. In fact, only one peer-reviewed paper performing a complete LCA of an aircraft was found [44] and one from an aircraft's wing [50], while the remaining works originate from theses and reports $[40,45,51,52]$. There are also a few available publications focusing on the comparison between metallic alloys and lightweight materials from an environmental point of view $[38,39,53]$. The social dimension of aircraft manufacturing has not been discussed so far, affirming the assumption of Nikolaou et al. (2021) [26] that most of engineering works tend to disregard it even in a context of sustainability assessment.

Howe et al. (2013) [54] conducted an LCA of A320 applying the Eco-Indicator method, where manufacturing phase was found to contribute with $0.089 \%$ to the life cycle. The main impact occurred mainly due to use of CFRP (responsible for $45 \%$ of the total manufacturing impact). While evaluating an Airbus A320-200 with ReCiPe Endpoint method, Johanning et al. (2013) [51] concluded that material production and other manufacturing-related processes bore less than $1 \%$ of the total aggregated impact. Both authors assumed that the aircraft was solely composed by aluminum, steel, titanium composites, and miscellaneous (without specification of what "miscellaneous" could mean). Jordão (2013) [52] have estimated only the embodied $\mathrm{CO}_{2}$-eq emissions, concluding that aircraft manufacturing was responsible for $0.05 \%$ of the total life cycle impact of an Airbus A330-200.

Lopes (2010) [45] conducted a comprehensive life cycle assessment with detailed data for the manufacturing, operation, and recycling of an A330-200. Three methods were applied: ReCiPe Midpoint, Cumulative Energy Demand [55], and Ecological Footprint [56]. Also here, the impact from manufacturing in most of the categories was very small (ca. $1 \cdot 10^{-6} \%$ ). Nevertheless, manufacturing was assessed in detail with ReCiPe midpoint method, concluding that the structure engine emerges as having the largest contribution in most of the categories. Wojcieh (2015) [40] used data obtained by Lopes (2010) [45], and by applying selected categories from ReCiPe Midpoint (climate change, terrestrial acidification, photochemical oxidant formation, particular matter formation) also obtained marginal contribution of the manufacturing phase.

Asmatulu et al. (2013) [42] and Ribeiro and Gomes (2014) [29] raised concerns about end-of-life and recycling of aircraft and made recommendations on recycling options. While Asmatulu et al. (2013) [42] focused on estimating energy savings from the use of recycled materials, Ribeiro and Gomes (2014) [29] developed a conceptual framework for integrating end-of-life (EoL) already in the preliminary design of the aircraft. Energy and cost savings were the most important aspects of the framework.

\section{ESSENZ Method}

The integrated method to assess resource efficiency (herein referred to as ESSENZ) [47, 48] allows for a comprehensive assessment of resources use by addressing environmental impacts, criticality, and long-term availability of resources as well as societal aspects of resource utilization. Further details are presented in the Supplementary Information - Sect. 1. 
For measuring the long-term availability of resources, the abiotic depletion potential (ADP) indicator based on ultimate reserves [57, 58] is applied. Criticality is assessed using an approach developed for ESSENZ, which was identified as one of the best approaches to address criticality aspects of products assessments [10,59]. The following potential supply disruptions are considered in the method: concentration of production, reserves and company concentration, feasibility of exploration projects, political stability, occurrence as co-product, mining capacity, primary material use, demand growth, price fluctuations, and trade barriers.

Societal impacts within the category societal acceptance are determined by two categories: compliance with social and environmental standards. As consumers and local communities become more interested in compliance with social and environmental standards, this can become an additional constraint for companies when purchasing resources. For measuring the category "Compliance with Social Standards", child labor, high conflict zones, and forced labor based on indicators of the Social Hotspot Database [60] are applied. The indicator to measure the category "Compliance with Environmental Standards" is the Environmental Performance Index (EPI) [61].

For the determination of environmental impacts, the life cycle impact assessment method CML-IA [62] is applied for the impact categories acidification, eutrophication, climate change, and photochemical ozone creation.

\section{Method}

In the following, the product system, the corresponding system boundaries, and the assumptions for the scenario with an increased share of lightweight composite materials are presented.

The functional unit was defined as 1 (one) aircraft A330-200. The aircraft A330-200 has been separated into six major structural components: wings, fuselage, vertical stabilizer, horizontal stabilizer, landing gear, and engine. The aircraft A330-200 can operate with different engine types. As only data for the General Electric model CF6-80E1 are available [45], this engine type is considered.

The weight of the aircraft is the manufacturer's empty weight (MEW) as defined by IVAO [63]. This includes the airframe structure and the engine, excluding the closed system fluids as well as internal components of the aircraft such as textiles due do lacking data. Electronic parts were examined only for the structure engine.

For determining the environmental impacts, the GaBi software with datasets of sphera [64] and ecoinvent [65] was used. For the resource criticality assessment, only the bill of materials (BoM) of which the aircraft is composed of has been taken into account.

The identification of the BoM of the product system is based on the work of Lopes [45], as shown on Table 1. As far as the authors are aware, no other data sources for aircraft are available. However, to ensure that the applied data is adequate, the authors discussed the $\mathrm{BoM}$ as well as some of the results with the major aircraft manufacturers that confirmed that the overall data quality is fair to good. More information on the detailed alloys considered are presented in the Supplementary Information - Sect. 2. Energy and water use for the complete airplane production was retrieved from Spielmann et al. [66], where a similar aircraft was analyzed.

As already shown in Fig. 1, there is a trend to produce aircraft with an increasingly higher share of composites. For the scenario presented in this paper, based on the example 
Table 1 Bill of materials (BoM) of A330-200 based on Lopes [45]

\begin{tabular}{lcl}
\hline Materials & Mass $(\mathrm{kg})$ & Mass $(\%)$ \\
\hline Aluminum alloy 2024 & 62,056 & 59 \\
Carbon fiber composites (CFRP) & 9,664 & 9 \\
Glass fiber composites (GFRP) & 1,086 & 1 \\
Titanium alloy & 8,116 & 8 \\
Steel alloy & 17,856 & 17 \\
Niobium and tantalum alloy & 188 & 0.01 \\
Iron-nickel-chromium alloy & 1,728 & 2 \\
Iron alloy & 912 & 1 \\
Nickel alloy & 2,948 & 3 \\
Chromium alloy & 894 & 1 \\
Overall sum & 105,448 & 100 \\
\hline
\end{tabular}

of the aircraft family A350 XWB, an aircraft with 53\% composites and $19 \%$ aluminum is assumed and modeled leading to weight savings of $15 \%$ compared to a "classical" aluminum-based aircraft $[4,37]$. Since the material substitution is usually realized in the wings and in the fuselage [67], it is assumed that the engine and the remaining parts of the aircraft remain the same weight. Due to lacking data to determine the GFRP share in modern aircraft, only the share of CFRP will be considered. The approach to determine the change in the overall weight of an aircraft is shown in the Supplementary Information - Sect. 3.

\section{Results}

In the following, the results of criticality including long-term availability ("Criticality Assessment Including Long-Term Availability"), environmental assessment ("Environmental Assessment"), recommendations regarding recycling of resources ("Recommendations Regarding Recycling of Resources"), and results for the scenario analysis for increased use of lightweight composite materials ("Scenario Analysis for Increased Use of Lightweight Composite Materials") are presented.

\section{Criticality Assessment Including Long-Term Availability}

\section{Results for Long-Term Availability of Resources}

First, results for the long-term availability applying the ADP indicator are presented (Fig. 2). Only the five resources with the highest impacts are shown, because the results of the other resources are comparably low and that they cannot be visualized. The complete assessment is presented in the Supplementary Information - Sect. 4. Molybdenum, which is mainly contained in the titanium, iron-nickel-chromium, and steel alloys, has the highest impacts and therefore the lowest long-term availability compared to the other resources of the aircraft. Results of copper (mostly contained in the aluminum 2024 alloy) and tin (present mostly in the titanium alloy) are high as well, whereas results of chrome and nickel are low. Overall, the engine is the structure with the most resources facing challenges 


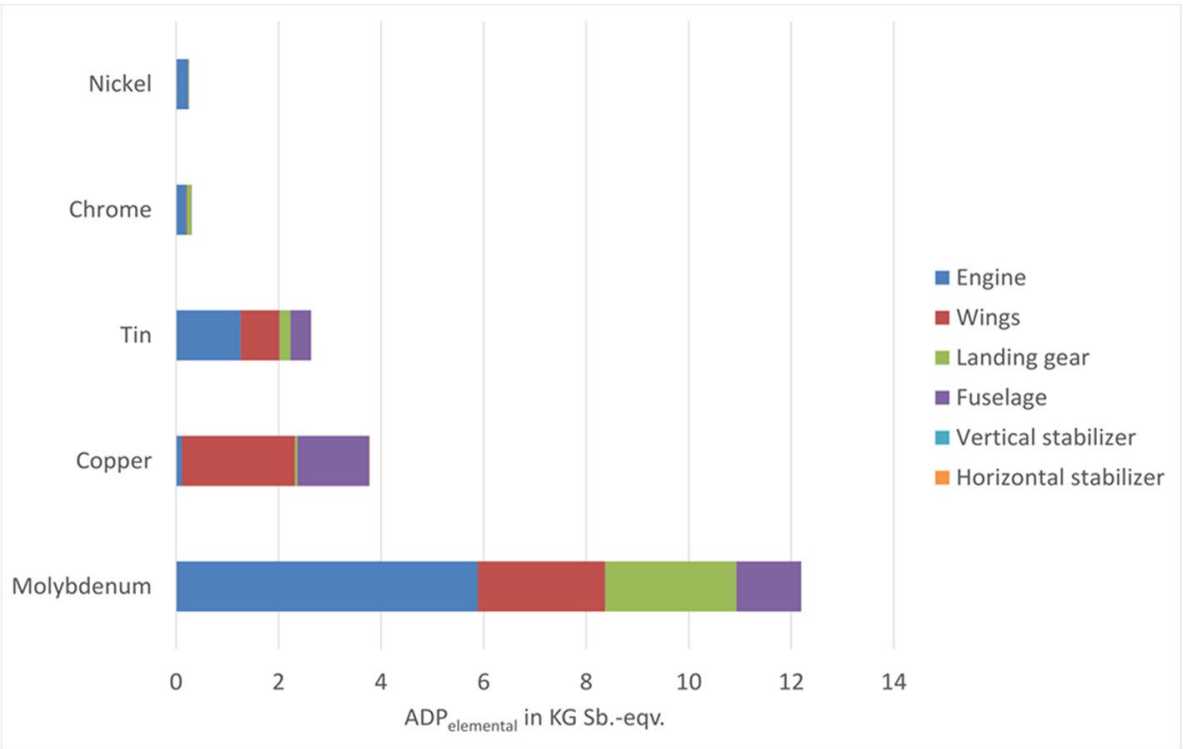

Fig. 2 Results of long-term availability

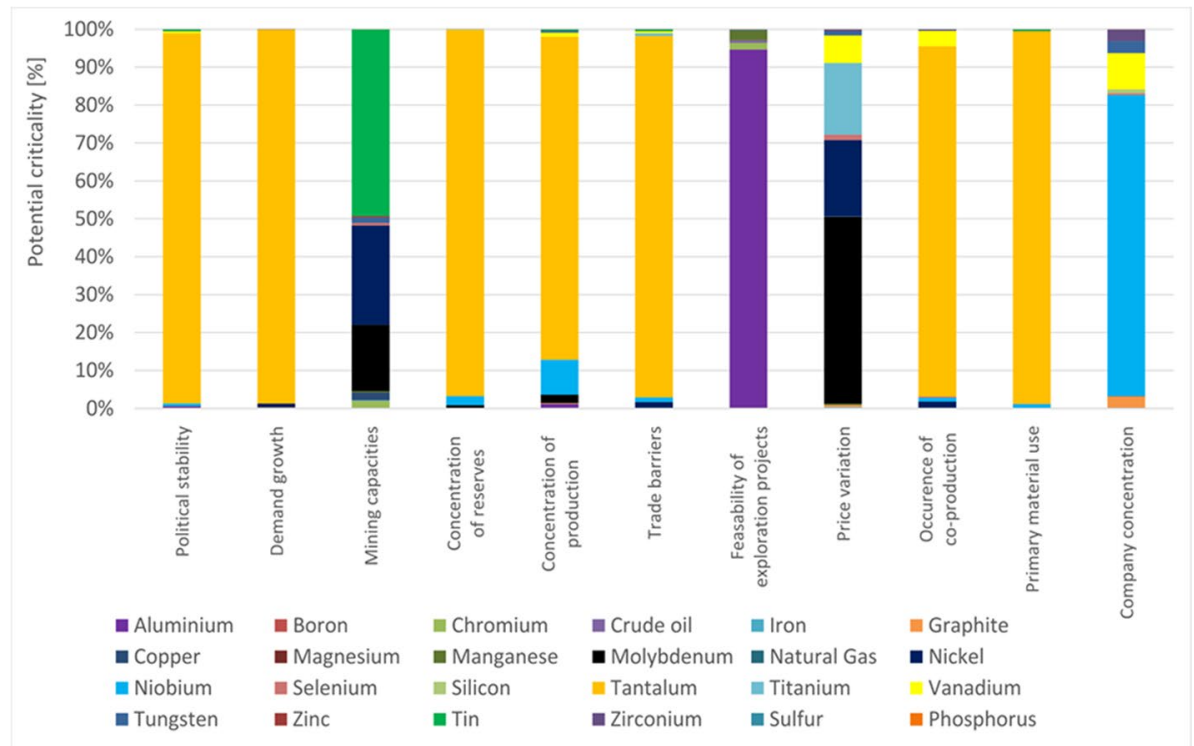

Fig. 3 Criticality results of aircraft A330-20 applying ESSENZ-method 
regarding long-term availability, followed by the wings and fuselage. Also when excluding the engine from the assessment, molybdenum, copper, and tin still remain the hotspots.

\section{Results for the Criticality of Resources}

Further, the results for criticality are presented (see Fig. 3). It can be seen that tantalum dominates most categories (except for mining capacity, feasibility of exploration projects, price variation, and company concentration), even though its quantity in the product system is rather small ( $0.1 \%$ by weight in the composition of the aircraft). Molybdenum, which faces the highest challenges regarding long-term availability, is not a hotspot in the criticality assessment and only shows a significant contribution in the category price variation. Again, the engine is the component of the aircraft showing the highest impact, mainly due to tantalum use (see Supplementary Information - Sect. 5 for a more detailed analysis of the different aircraft structures).

In the following, the hotspots of every category are explained:

- Political stability: Tantalum is a hotspot, because $40 \%$ of its production takes place in the Congo (Kinshasa) [68], which is characterized by political unrest [69, 70]. High amounts of tantalum are also produced in Rwanda (28\%), which faces high political instability as well $[71,72]$.

- Demand growth: Tantalum is a hotspot, because the growth of the electronics industry worldwide pushes its demand and already accounts for more than $50 \%$ of the global tantalum use [73]. As microelectronics use will further increase, tantalum demand is also expected to increase further.

- Mining capacity: Nickel, tin, and molybdenum are hotspots, because of their high yearly production on the one hand and only few active mines on the other hand [74, 75].

- Concentration of reserves and production: The predominance of tantalum in the category concentration of reserves can be explained by the fact that $70 \%$ of the known world reserves are located in Australia and 28\% in Brazil [68]. Even though the reserves are mainly located in these two countries, the production is dominated by Congo and Rwanda [68].

- Trade barriers: Tantalum is a hotspot, because its trade by Congo and Rwanda is influenced by the uncertain behavior of rebel groups and the unclear role of the government [76].

- Feasibility of exploration projects: The hotspot of aluminum can be explained by the fact that a relatively high share of its reserves (27\%) are located in Guinea. Stricter rules from the Guinea government obliging mining companies to incorporate social licenses into every mining process has led to fewer private investment interest [77].

- Price variation: This category is influenced by molybdenum and titanium. The prices of molybdenum have been highly fluctuating in the last years [78]. Titanium is the most demanded resource for the aerospace industry $30 \%$ of the total resource demand for that year) [9].

- Occurrence of co-production: Tantalum is a hotspot, because $33 \%$ of its production is linked to extraction of other resources, for example, in polymetallic mines (e.g., as a by-product of lithium production [68]) or from tin slag [79].

- Primary material use: Tantalum is a hotspot due to its low recycling rate and therefore small recycled content $[80,81]$. 
- Company concentration: Niobium is a hotspot, because more than $80 \%$ is produced by one Brazilian company [82, 83].

Based on the criticality results as well as the long-term availability, the engine is the aircraft structure influencing the results the most. Assessing the criticality when the engine is not considered can give further information on which resources might be critical.

When the engine is excluded, it can be verified that tantalum is not the hotspot anymore of the system (see Supplementary Information - Sect. 6). The largest contributors are then aluminum (in wings, landing gear, and fuselage), titanium (wings and fuselage), molybdenum (in fuselage), and vanadium (in wings).

\section{Results of the Dimension Societal Acceptance}

In the following, the results for the dimension societal acceptance are shown, which consists of two categories: non-compliance with environmental and non-compliance with social standards. The results are independent from the quantity of the used materials.

As shown in Fig. 4, overall the risk of non-complying with environmental standards is high for all materials. Tin, vanadium, and tantalum are hotspots. China is the largest producer of tin (40\%) and vanadium (61\%) [84] and has a high EPI value, meaning that the environmental performance of this country is low. Tantalum is mainly mined in Congo and Rwanda [68], having both countries a high EPI value and therefore also a low environmental performance. For the category non-compliance with social standards, tungsten and magnesium, whose production is dominated by China [85, 86], are the hotspots from the evaluation (Fig. 4).

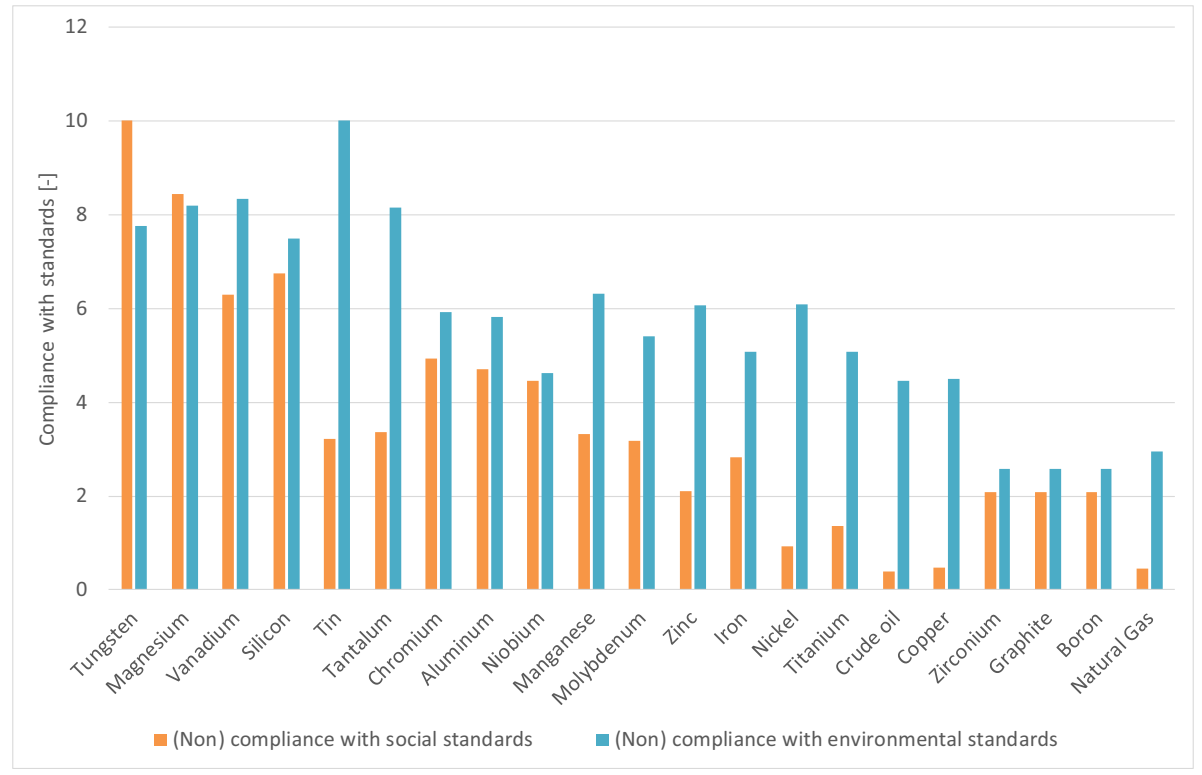

Fig. 4 Results for the category non-compliance with social and environmental standards 


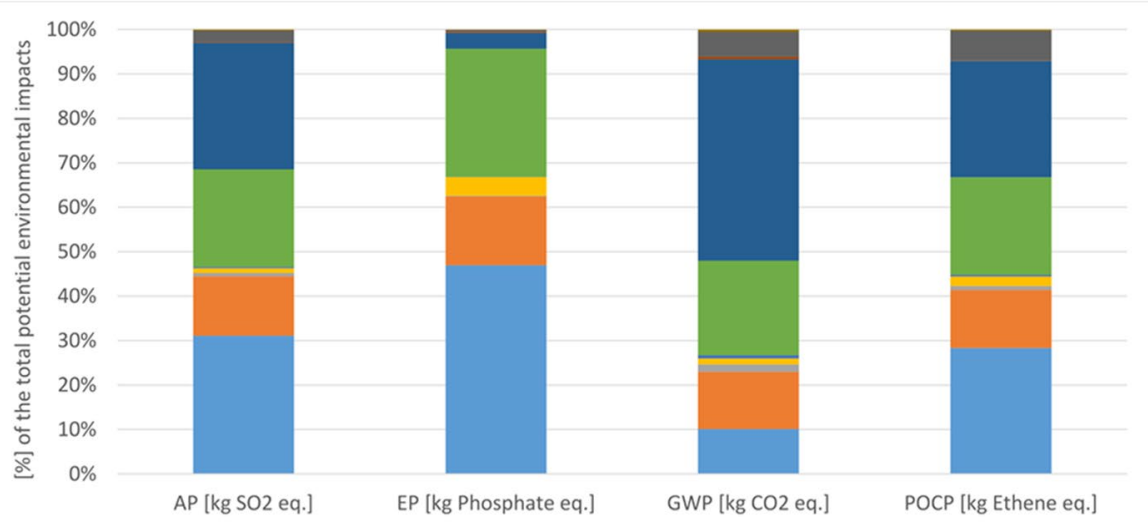

\begin{tabular}{|c|c|c|}
\hline Engine & - Fuselage & norizontal stabilizer structure \\
\hline Landing gear & - Vertical stabilizer structure & Wings \\
\hline Electricity & Municipal waste water treatment & Natural gas \\
\hline
\end{tabular}

Fig. 5 Environmental impacts of manufacturing of A330-200 aircraft

\section{Environmental Assessment}

Overall, the aircraft leads to $9.46 \cdot 10^{3} \mathrm{~kg}$ sulfur dioxide equivalents in the category acidification (AP), $7.05 \cdot 10^{3} \mathrm{~kg}$ phosphate equivalents in the category eutrophication (EP), 2.10 $\cdot 10^{6} \mathrm{~kg}$ carbon dioxide equivalents in the category climate change (GWP), and $6.43 \cdot 10^{2} \mathrm{~kg}$ ethene equivalents in the category smog (POCP). As shown in Fig. 5, the overall electricity use for building the aircraft is the hotspot in AP with 28\%, GWP with 45\%, and POCP with $26 \%$. The structures engine, wings, and fuselage have the highest impacts in all categories.

For AP, the aircraft's engine is responsible for $45 \%$ of the impacts due to the provision of nickel alloys. Aluminum alloys are responsible for $79 \%$ of total impacts of the wings and for $81 \%$ of the impacts of the fuselage. For EP, the engine contributes most to the impact (47\%), titanium being the hotspot with $94 \%$. For the wings, both aluminum contributes to $79 \%$ and titanium to $16 \%$. Overall, all titanium alloys are responsible for $95 \%$ of the total impacts, molybdenum being the largest contributor for this. During molybdenum processing, there is a high release of nitrates potentially leading to eutrophication of rivers and lakes [87]. The structures fuselage and wings are responsible for $71 \%$ of the total GWP impacts due to their large amount of aluminum alloy 2024 which is responsible for 56\% of total impact in the GWP considering all structures. The aluminum refining has a high energy demand, accounting for $11 \%$ of $\mathrm{CO}_{2}$-eq emissions among all metals [87]. The alloy 2024 itself contains cooper, manganese, and zinc which are also metals with high greenhouse gas emissions [8]. Further, the production of carbon fibers composites is responsible for $19 \%$ of the impact in GWP, mainly due to their high crude oil input. Finally, for POCP titanium (36\%) and nickel (40\%) — in the structure engine- -have the highest impact, whereas for the structures wings and fuselage, the aluminum (64\% for wings and $68 \%$ for fuselage) and titanium (27\% for wings and $25 \%$ for fuselage) production dominates. More detailed results for the environmental impacts can be found in the Supplementary 


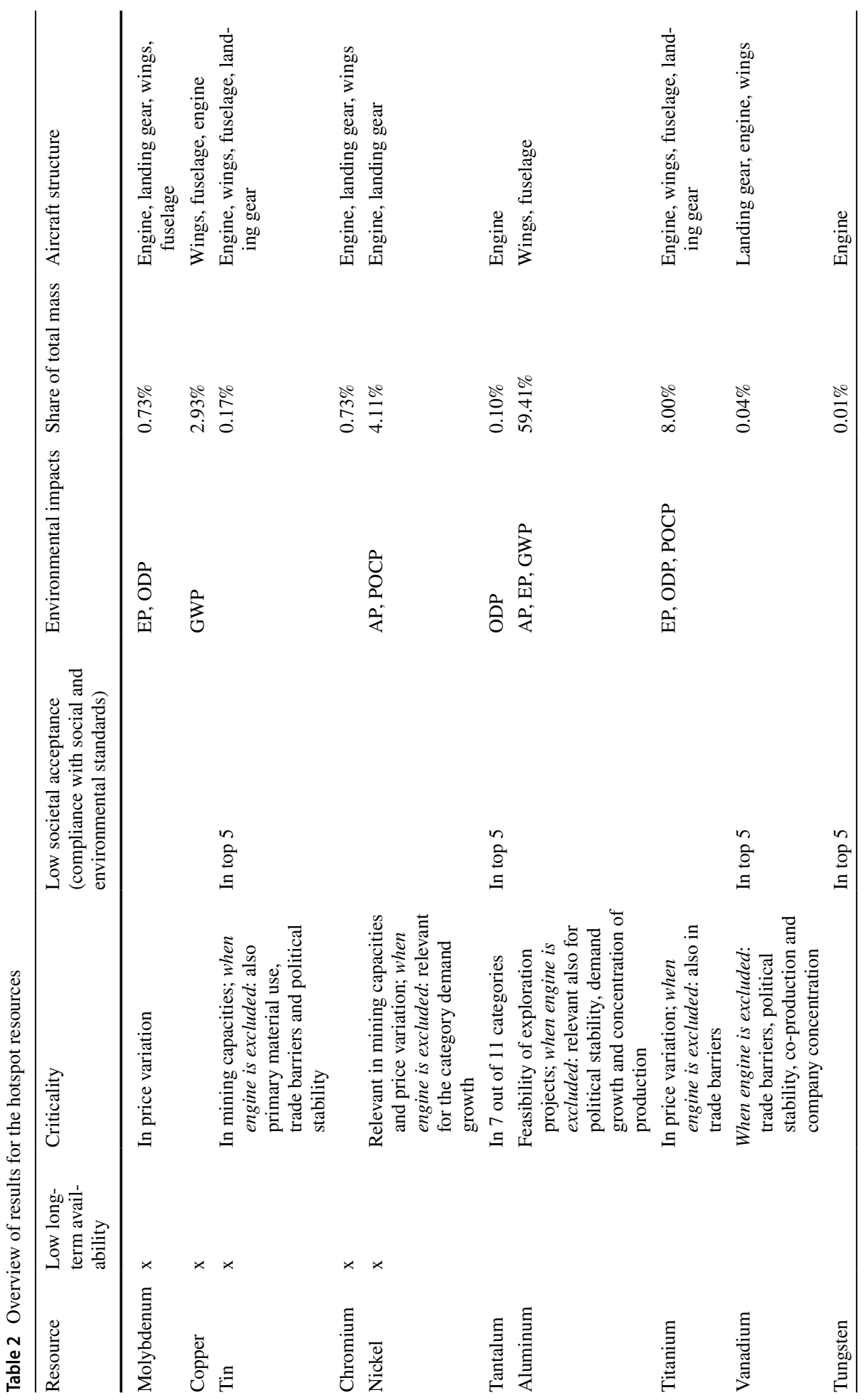




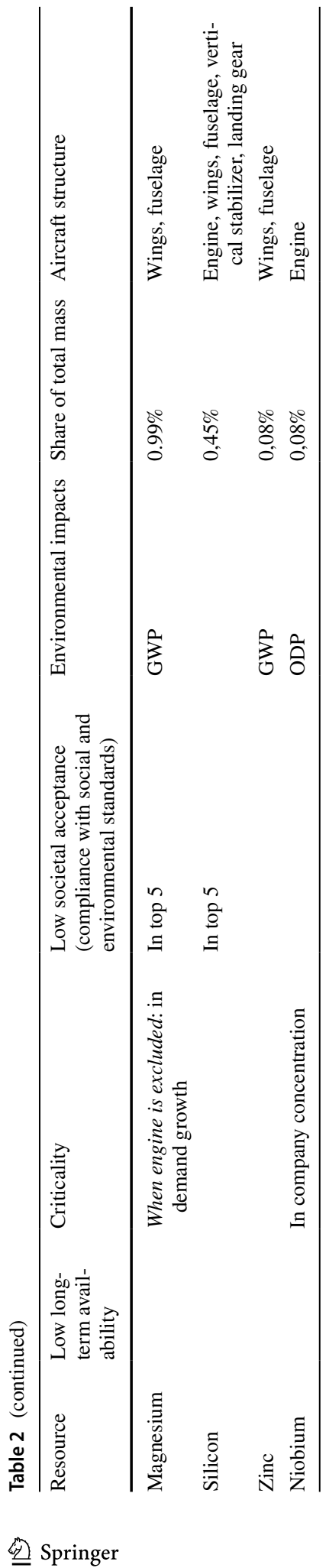


Information - Sect. 7. The alloys showing highest environmental impacts are nickel, aluminum, titanium, tantalum, and niobium.

\section{Recommendations Regarding Recycling of Resources}

Within Table 2, the results of the "Criticality Assessment Including Long-Term Availability" and the "Environmental Assessment" sections are summarized regarding the hotspots (ca. $78 \%$ of the total aircraft mass) identified for long-term availability, criticality, societal acceptance, and environmental impacts related to mass and aircraft structures.

It can be seen that the resource tin shows impacts in most of the considered categories; as its long-term availability is affected, it is influenced by criticality in the category mining capacities, and it is in the top 5 resources facing challenges with societal acceptance. Tin is contained in almost all aircraft structures, being a relevant part in the titanium alloys with a strengthening function. This also applies to molybdenum, which is a hotspot in most considered aspects except societal acceptance, being an important additive to titanium, ironnickel-chromium, and steel alloys.

Even though the mass share of both tin and molybdenum is very low, considering their relatively high impacts in most of the analyzed categories, it is recommended to recycle these resources in the respective alloys.

Aluminum is the main component of the most alloys contained in the fuselage ( $71 \%$ by mass) and in the wings ( $66 \%$ by mass), being a hotspot both from criticality as also from the environmental perspective. According to the last reported data, only approximately $20 \%$ of both aluminum is actually being recycled even though it is technologically feasible without much additional effort [42]. The recycling of this resource is thus strongly recommended.

Nickel and tantalum, both important elements in the engine, have been also identified as a hotspot resource for criticality and environmental impacts, emphasizing therefore the need for their recycling. Copper, titanium, vanadium, and magnesium are hotspots in two of the considered impact categories. Thus, their recycling should also be promoted. Titanium, vanadium, and magnesium are contained in aluminum 2024 and steel alloys, underlying once more the recycling need of these resources. Chromium, tungsten, silicon, zinc, and niobium each face only one hotspot, but should also not neglected. Chromium and silicon are also components of aluminum and steel alloys.

Next, the recycling of engine components such as tantalum, tungsten, and niobium shows a great potential to reduce criticality aspects (including societal acceptance) even though their mass may seem rather residual.

Even though iron, the main component of steel, does not show any evident hotspots in this assessment, due to the critical resources contained in this alloy, its recycling should also be prioritized. Overall, it can be thus stated that due to the hotspots of alloying resources, the recycling of aluminum 2024 and steel should be emphasized.

Resources used in composite materials have not shown any hotspots. Next, it will be analyzed if this changes when the share of composite materials is increased in aircraft construction.

\section{Scenario Analysis for Increased Use of Lightweight Composite Materials}

Figure 6 shows the changes in the results when increasing the share of composite materials in aircraft. The aircraft with $49 \%$ composite materials has higher impacts in GWP with 


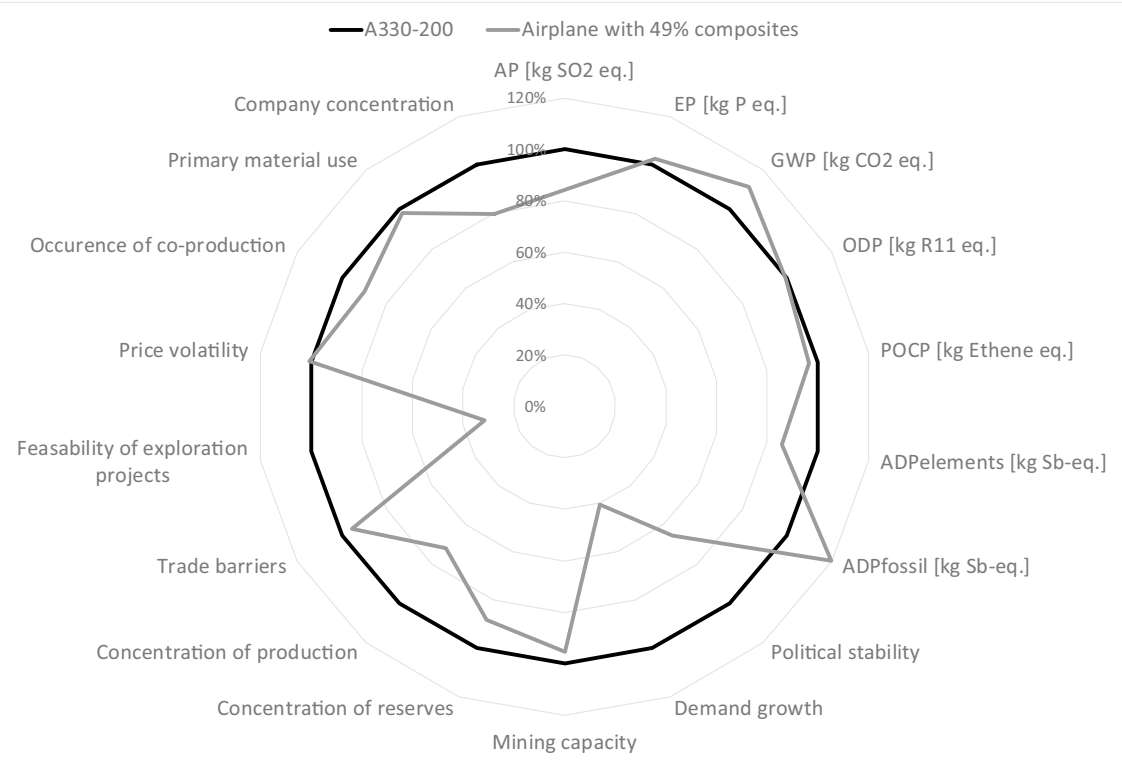

Fig. 6 Comparison of baseline scenario A330-200 and aircraft with 49\% composites

$12 \%$ and fossil resource depletion $\left(\mathrm{ADP}_{\text {fossil }}\right)$ with $20 \%$. Increases in these categories can be explained by the higher use of fossil fuels needed for carbon fibers composites made out of epoxy, which is crude oil-based.

The impacts of the composites-based aircraft are significantly lower for AP with 16\%, $\mathrm{ADP}_{\text {elements }}$ by $14 \%$, political stability with $35 \%$, demand growth with $60 \%$, concentration of reserves, production, and companies by $12 \%, 28 \%$, and $30 \%$, respectively. The biggest reduction occurs in the category feasibility of exploration projects with $68 \%$ impact reduction for the composite-based aircraft. These reductions can be explained by to the lower amount of aluminum, as explained in the results presented in "Criticality Assessment Including Long-Term Availability".

Even though the modeled aircraft with $49 \%$ composites scores better than A330-200 in several environmental categories, these results are not sufficient to derive further manufacturing recommendations. Higher GWP, $\mathrm{ADP}_{\text {fossil }}$, and the already mentioned difficulties for recycling composite materials might suppress eventual benefits achieved in the other categories (e.g., $\mathrm{AP}, \mathrm{ADP}_{\text {elements }}$, or criticality).

\section{Discussion}

The paper relayed mainly on data for aircraft manufacturing provided by only one publication [45], since no primary data from Airbus or other aircraft's manufacturers are available. A combination of sphera and ecoinvent databases was used to model the environmental impacts of aircraft manufacturing. As these databases rely on somewhat different modeling principles [88], this might also have influenced the results. Data for energy and water use were available just for the complete production process. For this reason, it was not possible to identify where the highest consumption take place. 
Several simplifications concerning the existing alloys in the aircraft and their composition were made. One is that the information on the alloys' composition was collected in secondary sources. The aluminum alloys for the aircraft industry are very diverse depending on their purpose. Even though aluminum alloy 2024 is the most common one, other configurations are used and could lead to different results in the individual dimensions. Also, the exact knowledge of the structure from CFRP and GFRP materials adopted in the aerospace industry was not known in detail, and assumptions based on literature were made regarding their exact composition. Such simplifications may explain why the differences between composites- and aluminum-based aircraft were not so significant in the environmental dimension.

It was shown that the engine component tantalum has the highest impacts in several criticality dimensions, despite its very small mass share. Tantalum has also been analyzed within another study [45], being pointed out as an environmental hotspot. Also nickel and aluminum were considered hotspots by previous publications [42, 45, 52]. Aluminum is also the material with the highest energy savings when recovered [42]. Therefore, a comparison of results was partly possible to validate the case study results. However, the environmental impacts of remaining raw resources (such as titanium and molybdenum) have not been analyzed in detail by other works.

As the aircraft structure engine shows several hotspots in the different dimensions and categories, a more detailed analysis of the remaining electronic parts such cables and navigation instruments should be carried out. Since no data is available for these electronics components, they were not considered in this paper.

To fully cover the impacts in all considered dimensions and also to identify potential trade-offs, composites should be deeper analyzed. This also includes the changing shares of other resources such as steel in the lightweight aircraft, as well as considering the use phase of the aircraft's service life and determining the break-even point when composites lead to lower environmental (as well as economic and societal) impacts by decreasing fuel consumption.

A further growth of the aircraft fleet would put more pressure on resources that are already considered critical. Thus, for future work, the EoL phase and different recycling strategies for the identified resources with high recycling potentials should be analyzed in more detail. The EoL might be especially relevant for the composite resources, because their recycling potential and more sustainable alternatives are still being researched [46, 89-92]. Further, for a complete picture, the use phase should be included as well.

\section{Conclusions}

By applying ESSENZ, this work has identified the major criticality and environmental hotspots of aircraft manufacturing. The engine of the aircraft is the structure with the potentially highest scarcity resources due to the use of tantalum. Engine, wings, and fuselage production lead to the highest environmental impacts due to aluminum, titanium, tantalum, molybdenum, and tin. Hotspots in the criticality and environmental assessment often occur in alloying resources with a low mass share. Thus, when it comes to recommendations regarding recycling, aluminum and steel alloys should be recycled. Next, within engine the resources tantalum, tungsten, and niobium should also be sourced from secondary sources. Clear advantages of using lightweight composite materials to reduce scarcity 
and environmental impacts during the manufacturing phase were not identified, and this is therefore not a relevant factor when only focusing on the manufacturing phase.

Herewith, the relevancy of analyzing the manufacturing phase of aircrafts was demonstrated as well as the advantages of promoting the recycling of decommissioned aircrafts in order to decrease the aircraft potential resource criticality. This might lead to a lower need for primary resources as well as to diminished environmental impacts, contributing therefore to reduce the overall impact of the aviation sector in line with circular economy principles.

Supplementary Information The online version contains supplementary material available at https://doi. org/10.1007/s43615-022-00157-x.

Author Contribution Conceptualization: I.D. and V.B. Data curation: I.D. and V.B. Funding acquisition: M.F., M.K., V.B., and A.R. Investigation: I.D. and V.B. Methodology: I.D., V.B., and M.F. Project administration: all authors. Supervision: V.B., M.F., A.R., and M.K. Validation: all authors. Visualization: I.D, V.B., and A.R. Roles/writing—original draft: I.D., V.B., and M.F. Writing—review and editing: all authors.

Funding Open Access funding enabled and organized by Projekt DEAL. This work was supported by the Deutsche Forschungsgesellschaft (DFG) under Grant number: FI 1622/6-1 (project RessMob: Assessment of abiotic and biotic resources within the mobility sector - development of assessment criteria, methods, and concepts).

Availability of Data and Material Data can be found in the supplementary material.

Code Availability No code was used.

\section{Declarations}

Ethics Approval Not applicable.

Consent to Participate Not applicable.

Consent for Publication Not applicable.

Conflict of Interest The authors declare no competing interests.

Open Access This article is licensed under a Creative Commons Attribution 4.0 International License, which permits use, sharing, adaptation, distribution and reproduction in any medium or format, as long as you give appropriate credit to the original author(s) and the source, provide a link to the Creative Commons licence, and indicate if changes were made. The images or other third party material in this article are included in the article's Creative Commons licence, unless indicated otherwise in a credit line to the material. If material is not included in the article's Creative Commons licence and your intended use is not permitted by statutory regulation or exceeds the permitted use, you will need to obtain permission directly from the copyright holder. To view a copy of this licence, visit http://creativecommons.org/licenses/by/4.0/.

\section{References}

1. Trefis Team (2016) What Are The Factors Behind Soaring Air Travel Growth? https://www.forbes. com/sites/greatspeculations/2016/08/30/what-are-the-factors-behind-soaring-air-travel-growth/\#42aaf c85258d. Accessed 10 June 2021

2. statista (2019) Annual growth in global air traffic passenger demand from 2006 to 2019. https://www. statista.com/statistics/193533/growth-of-global-air-traffic-passenger-demand/. Accessed 10 June 2021

3. IATA (2018) Forecast Predicts 8.2 billion Air Travelers in 2037. https://www.iata.org/en/pressroom/pr/ 2018-10-24-02/. Accessed 12 July 2021 
4. Airbus (2018) Global Market Forecast 2018-2037. https://www.airbus.com/en/newsroom/press-relea ses/2018-07-airbus-forecasts-46-trillion-worldwide-market-for-commercial\#: :text=Airbus'\%20new\% 20Global\%20Services\%20Forecast,operation $\% 2$ C $\% 20$ and $\% 20$ the $\% 20$ passenger $\% 20$ experience. Accessed 01 March 2020

5. Boeing (2018) Commercial Outlook 2018-2037. https://www.boeing.com/commercial/market/comme rcial-market-outlook/. Accessed 01 March 2020

6. BDI (2017) Rohstoffversorgung 4.0. https://bdi.eu/publikation/news/rohstoffversorgung-4-0/ Accessed 02 July 2020

7. UNEP (2019) Global Resources Outlook. https://wedocs.unep.org/handle/20.500.11822/27521;jsess ionid=9B67BCB6D6C37089049F217B3363EE0E. Accessed 02 July 2020

8. OECD (2018) Global Material Resources Outlook to 2060. https://www.oecd.org/environment/waste/ highlights-global-material-resources-outlook-to-2060.pdf. Accessed 02 July 2020

9. Michaels K, Up, Front (2018) Aviat Week Space Technol. https://doi.org/10.1215/01610775-24-1-5

10. Sonderegger T, Berger M, Alvarenga R, Bach V, Cimprich A, Dewulf J, Frischknecht R, Guinée J, Helbig C, Huppertz T, Jolliet O, Motoshita M, Northey S, Rugani B, Schrijvers D, Schulze R, Sonnemann G, Valero A, Weidema BP, Young SB (2020) Mineral resources in life cycle impact assessment-part I: a critical review of existing methods. Int J Life Cycle Assess. https://doi.org/10.1007/ s11367-020-01736-6

11. Graedel T, Reck BK (2016) Six years of criticality assessments: what have we learned so far? J Ind Ecol 20:692-699. https://doi.org/10.1111/jiec.12305

12. Cimprich A, Bach V, Helbig C, Thorenz A, Schrijvers D, Sonnemann G, Young S, Sonderegger T, Berger M (2019) Raw material criticality assessment as a complement to environmental life cycle assessment: Examining methods for product-level supply risk assessment. J Ind Ecol.https://doi.org/10. 1111/jiec. 12865

13. Arendt R, Muhl M, Bach V, Finkbeiner M (2020) Criticality assessment of abiotic resource use for Europe-application of the SCARCE method. Resour Policy 67:101650. https://doi.org/10.1016/j. resourpol.2020.101650

14. European Commission (2017) Methodology for establishing the EU list of critical raw materials. Brussels, Belgium

15. SNIFFER (2011) Raw materials critical to the Scottish economy. https://www.sepa.org.uk/media/ 163165/raw_materials_final_project_report.pdf. Accessed 20 June 2020

16. Schrijvers D, Hool A, Blengini GA, Chen W-Q, Dewulf J, Eggert R, van Ellen L, Gauss R, Goddin J, Habib K, Hagelüken C, Hirohata A, Hofmann-Amtenbrink M, Kosmol J, Le Gleuher M, Grohol M, Ku A, Lee M-H, Liu G, Nansai K, Nuss P, Peck D, Reller A, Sonnemann G, Tercero L, Thorenz A (2020) Wäger, P. A. A review of methods and data to determine raw material criticality. Resour Conserv Recycl 155:104617. https://doi.org/10.1016/j.resconrec.2019.104617

17. Helbig C, Bradshaw AM, Kolotzek C, Thorenz A, Tuma A (2016) Supply risks associated with CdTe and CIGS thin-film photovoltaics. Appl Energy 178:422-433. https://doi.org/10.1016/j.apene rgy.2016.06.102

18. Helbig C, Bradshaw AM, Wietschel L, Thorenz A, Tuma A (2018) Supply risks associated with lithium-ion battery materials. J Clean Prod 172:274-286. https://doi.org/10.1016/j.jclepro.2017.10. 122

19. Yuan Y, Yellishetty M, Mudd GM, Muñoz MA, Northey SA, Werner TT (2020) Toward dynamic evaluations of materials criticality: A systems framework applied to platinum. Resour Conserv Recycl 152:104532. https://doi.org/10.1016/j.resconrec.2019.104532

20. Yavor KM, Bach V, Finkbeiner M (2021) Resource assessment of renewable energy systems-a review sustainability 13:6107. https://doi.org/10.3390/su13116107

21. Sun X, Bach V, Finkbeiner M, Yang J (2021) Criticality assessment of the life cycle of passenger vehicles produced in China. Circ Econ Sustain. https://doi.org/10.1007/s43615-021-00012-5

22. Henßler M, Bach V, Berger M, Finkbeiner M, Ruhland K (2016) Resource efficiency assessmentcomparing a plug-in hybrid with a conventional combustion engine. Resources. https://doi.org/10. 3390/resources5010005

23. Greim P, Solomon AA, Breyer C (2020) Assessment of lithium criticality in the global energy transition and addressing policy gaps in transportation. Nat Commun 11:4570. https://doi.org/10.1038/ s41467-020-18402-y

24. Bongartz L, Shammugam S, Gervais E, Schlegl T (2021) Multidimensional criticality assessment of metal requirements for lithium-ion batteries in electric vehicles and stationary storage applications in Germany by 2050. J Clean Prod 292:126056. https://doi.org/10.1016/j.jclepro.2021.126056 
25. Dolganova I, Rödl A, Bach V, Kaltschmitt M, Finkbeiner M (2020) Review of life cycle assessment studies of electric vehicles with a focus on resource use. Resources. https://doi.org/10.3390/resou rces 9030032

26. Nikolaou IE, Jones N, Stefanakis A (2021) Circular economy and sustainability: the past, the present and the future directions. Circ Econ Sustain 1:1-20. https://doi.org/10.1007/s43615-021-00030-3

27. Bach V, Berger M, Henßler M, Kirchner M, Leiser S, Mohr L, Rother E, Ruhland K, Schneider L, Tikana L, Volkhausen W, Walachowicz F, Finkbeiner M (2016) Integrated method to assess resource efficiency - ESSENZ. J Clean Prod 137:118-130. https://doi.org/10.1016/j.jclepro.2016. 07.077

28. Boeing (2018) The Boeing Company Conflict Minerals Report For The Year Ended December 31, 2018. https://www.sec.gov/Archives/edgar/data/12927/000001292719000042/a201812dec31con flictmineral.htm. Accessed 05 July 2020

29. Ribeiro JS, Gomes JD (2014) O. A framework to integrate the end-of-life aircraft in preliminary design. Procedia CIRP 15:508-513. https://doi.org/10.1016/j.procir.2014.06.077

30. Wright $\mathrm{T}$ (2014) When airliners vanish. https://www.smithsonianmag.com/air-space-magazine/ when-airliners-vanish-180952793/. Accessed 01 March 2020

31. AFRA (2017) Best Management Practice for Managementof Used Aircraft Parts and Assemblies and for Recycling of Aircraft Materials. http://afraassociation.org/wp-content/uploads/2016/03/ AFRA-BMP-Guide-3.3-Fillable-Disassembly-Checklist-1.pdf. Accessed 01 March 2020

32. Malavallon O (2009) PAMELA-Life. https://www.espace-pau-aviation.fr/images/docs-pdf/091127_ expose11_malavallon.pdf. Accessed 02 June 2019

33. TARMAC (2019) Aerosave. http://www.tarmacaerosave.aero. Accessed 04 April 2019

34. Asmatulu E, Overcash M, Twomey J (2013) Recycling of aircraft: state of the art in 2011. J Ind Eng 2013:1-8. https://doi.org/10.1155/2013/960581

35. Calado EA, Leite M, Silva A (2018) Selecting composite materials considering cost and environmental impact in the early phases of aircraft structure design. J Clean Prod 186:113-122. https:// doi.org/10.1016/j.jclepro.2018.02.048

36. Witik RA, Gaille F, Teuscher R, Ringwald H, Michaud V, Månson JAE (2012) Economic and environmental assessment of alternative production methods for composite aircraft components. J Clean Prod 29-30:91-102. https://doi.org/10.1016/j.jclepro.2012.02.028

37. Airbus (2016) A350 XWB: Facts and Figures. https://asds-media.com/data/a350-xwb-facts-figuresm1882. Accessed 26 June 2019

38. Scelsi L, Bonner M, Hodzic A, Soutis C, Wilson C, Scaife R, Ridgway K (2011) Potential emissions savings of lightweight composite aircraft components evaluated through life cycle assessment. Express Polym Lett 5:209-217. https://doi.org/10.3144/expresspolymlett.2011.20

39. Timmis AJ, Hodzic A, Koh L, Bonner M, Soutis C, Schfer AW, Dray L (2015) Environmental impact assessment of aviation emission reduction through the implementation of composite materials. Int J Life Cycle Assess 20:233-243. https://doi.org/10.1007/s11367-014-0824-0

40. Wojcieh J (2015) Life cycle assessment of current and future passenger air transport in Switzerland. Master thesis, University of Nordland

41. Ilg R (2015) Ein methodischer Ansatz zur ökologischen Betrachtung von Luftfahrtsystemen. Dissertation, Universität Stuttgart

42. Asmatulu E, Twomey J, Overcash M (2013) Evaluation of recycling efforts of aircraft companies in Wichita. Resour Conserv Recycl 80:36-45. https://doi.org/10.1016/j.resconrec.2013.08.002

43. Reckter B (2018) Gerettet? Recycling von faserverstärkten Kunststoffen. https://www.vdi-nachr ichten.com/technik/umwelt/gerettet-recycling-von-faserverstaerkten-kunststoffen/. Accessed 20 June 2019

44. Howe S, Kolios A, Brennan F (2013) Environmental life cycle assessment of commercial passenger jet airliners. Transp Res Part D Transp Environ 19:34-41. https://doi.org/10.1016/J.TRD.2012.12. 004

45. Lopes J (2010) Life Cycle Assessment of the Airbus A330-200 Aircraft. Master thesis, Universidade Técnica de Lisboa

46. Bachmann J, Yi X, Tserpes K, Sguazzo C, Barbu LG, Tse B, Soutis C, Ram E, Linuesa H (2021) Towards a circular economy in the aviation sector using eco-composites for interior and secondary structures. Results and Recommendations from the EU/China Project ECO-COMPASS. Aerospace 5:131. https://doi.org/10.3390/aerospace8050131

47. Bach V, Berger M, Henßler M, Kirchner M, Leiser S, Mohr L, Rother E, Ruhland K, Schneider L, Tikana L, Volkhausen W, Walachowicz F, Finkbeiner M (2016) Integrated method to assess resource efficiency - ESSENZ. J Clean Prod 137:118-130. https://doi.org/10.1016/j.jclepro.2016. 07.077 
48. Bach V, Berger M, Finogenova N, Finkbeiner M (2019) Analyzing changes in supply risks for abiotic resources over time with the ESSENZ method-a data update and critical reflection. Resources 8:83. https://doi.org/10.3390/resources8020083

49. ATDB.aero (2021) AeroTransport. http://www.aerotransport.org. Accessed 23 December 2021

50. Vieira DR, Bravo A (2016) Life cycle carbon emissions assessment using an eco-demonstrator aircraft: the case of an ecological wing design. J Clean Prod 124:246-257. https://doi.org/10.1016/j. jclepro.2016.02.089

51. Johanning A, Scholz D, Tor B (2013) A first step towards the integration of life cycle assessment into conceptual aircraft design. https://www.fzt.haw-hamburg.de/pers/Scholz/Airport2030/Airport2030_ PUB_DLRK_13-09-10.pdf. Accessed 17 May 2019

52. Jordão TC (2013) Life Cycle Assessment oriented to climate change mitigation by aviation. https:// www.researchgate.net/profile/Ticiano-Jordao/publication/261403034_Life_Cycle_Assessment_ oriented_to_climate_change_mitigation_by_aviation/links/0c960534317d50a578000000/LifeCycle-Assessment-oriented-to-climate-change-mitigation-by-aviation.pdf. Accessed 01 September 2020

53. Huang R, Riddle M, Graziano D, Warren J, Das S, Nimbalkar S, Cresko J, Masanet E (2016) Energy and emissions saving potential of additive manufacturing: the case of lightweight aircraft components. J Clean Prod 135:1559-1570. https://doi.org/10.1016/j.jclepro.2015.04.109

54. Howe S, Kolios AJ, Brennan FP (2013) Environmental life cycle assessment of commercial passenger jet airliners. Transp Res Part D Transp Environ 19:34-41. https://doi.org/10.1016/j.trd.2012.12.004

55. Stamp A, Lang DJ, Wäger PA (2012) Environmental impacts of a transition toward e-mobility: The present and future role of lithium carbonate production. J Clean Prod 23:104-112. https://doi.org/ 10.1016/j.jclepro.2011.10.026

56. Lee S-J, Hawkins TR, Ingwersen WW, Young DM (2015) Exploring the use of ecological footprint in life cycle impact assessment: findings from a comparison of transportation fuels. J Ind Ecol 19:416-426. https://doi.org/10.1111/jiec. 12188

57. Guinée JB, Udo de Haes HA, Huppes (1993) Quantitative life cycle assessment of products - 2. Classification, valuation and improvement analysis. J Clean Prod https://doi.org/10.1016/09596526(93)90046-E

58. van Oers L, de Koning A, Guinée JB, Huppes G (2002) Abiotic ressource depletion in LCA Improving characterisation factors for abiotic resource depletion as recommended in the Dutch LCA Handbook. https://www.leidenuniv.nl/cml/ssp/projects/lca2/report_abiotic_depletion_web. pdf. Accessed 20 May 2019

59. Berger M, Sonderegger T, Alvarenga R, Bach V, Cimprich A, Dewulf J, Frischknecht R, Guinée J, Helbig C, Huppertz T, Jolliet O, Motoshita M, Northey S, Peña CA, Rugani B, Sahnoune A, Schrijvers D, Schulze R, Sonnemann G, Valero A, Weidema BP, Young SB (2020) Mineral resources in life cycle impact assessment: part II - recommendations on application-dependent use of existing methods and on future method development needs. Int J Life Cycle Assess. https://doi.org/10.1007/ s11367-020-01737-5

60. Benoît-Norris C, Norris GA, Aulisio CD (2013) Social hotspots database: supporting documentation. New Earth, 2013

61. Yale Center for Environmental Law \& Policy (2019) Environmental Performance Index. http://epi. yale.edu/. Accessed 05 May 2019

62. Department of Industrial Ecology Leiden University (2019) CML-IA Characterisation Factors. https://www.universiteitleiden.nl/en/research/research-output/science/cml-ia-characterisation-facto rs. Accessed 03 November 2020

63. IVAO (2015) Aircraft Weights. https://www.ivao.aero/training/documentation/books/SPP_aircraft_ weight.pdf. Accessed 26 June 2020

64. sphera (2021) GaBi Product Sustainability Software. https://gabi.sphera.com. Accessed 01 December 2021

65. Ecoinvent (2021) Ecoinvent database. https://ecoinvent.org. Accessed 01 December 2021

66. Spielmann M, Bauer C, Dones R, Tuchschmid M (2007) Transport services.https://db.ecoinvent. org/reports/14_transport.pdf. Accessed 20 June 2020

67. Airbus (2019). Airbus continues to shape the future. https://www.airbus.com/newsroom/news/en/ 2017/08/composites--airbus-continues-to-shape-the-future.html. Accessed 20 June 2020

68. U.S. Geological Survey (2021) Mineral Commodity Summaries: Tantalum. https://pubs.usgs.gov/ periodicals/mcs2021/mcs2021-tantalum.pdf. Accessed 19 December 2021

69. Stearns JK (2017) The Democratic Republic of the Congo: an elusive peace. War and Peace in Africa's Great Lakes Region. Springer International Publishing, Cham, pp 33-47 
70. Vogel, (2018) Between tags \& guns : fragmentations of public authority around eastern Congo's artisanal 3T mines. Polit Geogr 63:94-103. https://doi.org/10.1016/j.polgeo.2017.06.012

71. Mancheri NA (2015) World trade in rare earths, Chinese export restrictions, and implications. Resour Policy 46:262-271. https://doi.org/10.1016/j.resourpol.2015.10.009

72. Vogel C, Raeymaekers T (2016) Terr(it)or(ies) of peace? The Congolese mining frontier and the fight against conflict minerals. Antipode 48:1102-1121. https://doi.org/10.1111/anti.12236

73. United States Geological (2016) Minerals Yearbook: Tantalum. https://prd-wret.s3-us-west-2. amazonaws.com/assets/palladium/production/atoms/files/myb1-2016-tanta.pdf. Accessed 12 September 2019

74. Henckens MLCM, van Ierland EC, Driessen PPJ, Worrell E (2016) Mineral resources: Geological scarcity, market price trends, and future generations. Resour Policy 49:102-111. https://doi.org/10. 1016/j.resourpol.2016.04.012

75. Nakajima K, Nansai K, Matsubae K, Tomita M, Takayanagi W, Nagasaka T (2017) Global landuse change hidden behind nickel consumption. Sci Total Environ 586:730-737. https://doi.org/10. 1016/j.scitotenv.2017.02.049

76. Smith JH (2015) May it never end. HAU J Ethnogr Theory 5:1-34. https://doi.org/10.14318/hau5.1. 002

77. Sing J (2015) Regulating mining resource investments towards sustainable development: The case of Papua New Guinea. Extr Ind Soc 2:124-131. https://doi.org/10.1016/j.exis.2014.11.003

78. Trading Economics (2021) Molybdenum. https://tradingeconomics.com/commodity/molybden. Accessed 12 October 2020

79. Mancheri NA, Sprecher B, Deetman S, Young SB, Bleischwitz R, Dong L, Kleijn R, Tukker A (2018) Resilience in the tantalum supply chain. Resour Conserv Recycl 129:56-69. https://doi.org/ 10.1016/j.resconrec.2017.10.018

80. UNEP (2011) Recycling rates of metals - a status report. https://wedocs.unep.org/handle/20.500. 11822/8702. Accessed 25 June 2020

81. Ueberschaar M, Dariusch Jalalpoor D, Korf N, Rotter VS (2017) Potentials and Barriers for Tantalum Recovery from Waste Electric and Electronic Equipment. J Ind Ecol 21:700-714. https://doi. org/10.1111/jiec. 12577

82. CBMM (2018) About CBMM. http://www.cbmm.com.br/. Accessed 18 June 2020

83. Dolganova I, Bosch F, Bach V, Baitz M, Finkbeiner M (2020) Life cycle assessment of ferro niobium. Int J Life Cycle Assess 25:611-619. https://doi.org/10.1007/s11367-019-01714-7

84. United States Geological Survey (2021) Vanadium. https://pubs.usgs.gov/periodicals/mcs2021/ mcs2021-vanadium.pdf. Accessed 21 December 2021

85. United States Geological Survey (2021) Magnesium. https://pubs.usgs.gov/periodicals/mcs2021/ mcs2021-magnesium-metal.pdf. Accessed 20 December 2021

86. United States Geological Survey (2021) Tungsten. https://pubs.usgs.gov/periodicals/mcs2021/ mcs2021-tungsten.pdf. Accessed 20 December 2021

87. Nuss P, Eckelman MJ (2014) Life cycle assessment of metals: a scientific synthesis. PLoS ONE 9:1-12. https://doi.org/10.1371/journal.pone.0101298

88. Baitz M, Makishi Colodel C, Kupfer T, Pflieger J, Schuller O, Hassel F, Fong L (2019) GaBi database and modelling principles. Leinfelden-Echterdingen, Germany

89. Meng F, McKechnie J, Turner T, Wong KH, Pickering SJ (2017) Environmental aspects of use of recycled carbon fiber composites in automotive applications. Environ Sci Technol 51:1272712736. https://doi.org/10.1021/acs.est.7b04069

90. Borjan D, Knez Ž, Knez M (2021) Recycling of carbon fiber-reinforced composites-difficulties and future perspectives. Materials (Basel) 14:4191. https://doi.org/10.3390/ma14154191

91. Giorgini L, Benelli T, Brancolini G, Mazzocchetti L (2020) Recycling of carbon fiber reinforced composite waste to close their life cycle in a cradle-to-cradle approach. Curr Opin Green Sustain Chem 26:100368. https://doi.org/10.1016/j.cogsc.2020.100368

92. Rosenbaum RK, Bachmann TM, Jolliet O, Juraske R, Koehler A, Hauschild MZ (2008) USEtox-the UNEP-SETAC toxicity model: recommended characterisation factors for human toxicity and freshwater ecotoxicity in life cycle impact assessment. Int J LCA 13:532-546. https://doi.org/10.1007/ s11367-008-0038-4

Publisher's Note Springer Nature remains neutral with regard to jurisdictional claims in published maps and institutional affiliations. 